\title{
KARAKTERISTIK MUSIKAL PADA FILM TENGGELAMNYA KAPAL VAN DER WIJCK
}

\author{
Haria Nanda Pratama ${ }^{1 *}$, Abdul Rozak ${ }^{2 *}$ \\ Program Studi Seni Teater ${ }^{*}$ \\ Program Studi Seni Karawitan ${ }^{2 *}$ \\ Jurusan Seni Pertunjukan \\ Institut Seni Budaya Indonesia Aceh \\ Jl. Transmigrasi, Gampong Buket Meusara, Kec. Kota Jantho, Kab. Aceh Besar, Kode Pos 23911 \\ Aceh. Indonesia \\ Email: harianandapratama@gmail.com; abdulrozak.isbiaceh@gmail.com
}

\begin{abstract}
Abstrak
Film Tenggelamnya Kapal Van Der Wijck merupakan sebuah film drama yang dirilis pada tanggal 19 Desember 2013. Film Tenggelamnya Kapal Van Der Wijck yang disutradarai Sunil Soraya dan diproduksi oleh Ram Soraya ini diadaptasi dari novel mahakarya sastrawan sekaligus budayawan Haji Abdul Malik Karim Amrullah, atau yang biasa dikenal dengan Buya Hamka. Film ini mengisahkan tentang pertentangan dan konflik karena perbedaan status sosial. Hal ini didukung oleh efek musik dalam menciptakan suasana di dalam setiap adegan yang meliputi dialog dan aksi tokoh yang didukung oleh latar waktu, tempat serta suasana pada film. Objek penelitian ini berfokus pada salah satu unsur sinematik pada film Tenggelamnya Kapal Van Der Wijck, yaitu musik atau suara. Musik dan suara menjadi salah satu unsur yang membangun latar waktu, tempat, dan suasana pada film, yang berpengaruh pada mood penonton. Musik dan suara tersebut berguna untuk menambah efek dramatis ketika adegan-adegan pada alur cerita yang terlihat di setiap pengambilan gambar (shot, scene, dan sequence). Karakteristik musik pada film Tenggelamnya Kapal Van Der Wijck yang meliputi irama, melodi, harmoni, tempo, struktur lagu dan warna bunyi menghasilkan suasana film sesuai dengan adegan di dalam film yang dianggap memiliki peran yang penting dalam membangun efek dramatis pada film yang mempengaruhi mood penonton. Penelitian ini dilakukan dengan pendekatan kualitatif dengan metode analisis deskriptif. Sumber datanya adalah pengamatan langsung atas film Tenggelamnya Kapal Van Der Wijck. Tahap pengumpulan data dilakukan peneliti adalah mengumpulkan dokumen yang meliputi VCD original film dan studi Pustaka yang meliputi buku dan tulisan ilmiah sebagai bahan komparasi yang berkaitan dengan objek material dan objek formal pada penelitian ini. Berdasarkan data tersebut, dilakukan analisis terhadap karakteristik musikal pada film Tenggelamnya Kapal Van Der Wijck. Hasil penelitian akan menunjukkan bahwa musik dalam pemakaian instrumen musik, tangganada mayor atau minor, dinamika, motif, dan tempo menjadi karakteristik dalam membangun efek dramatis pada film.
\end{abstract}

Kata Kunci: tenggelamnya kapal Van Der Wijck.

\begin{abstract}
The film Tenggelamnya Kapal Van Der Wijck is a drama film released on December 19, 2013. The film Tenggelamnya Kapal Van Der Wijck, directed by Sunil Soraya and produced by Ram Soraya, is adapted from a novel by the writer and cultural expert Haji Abdul Malik Karim Amrullah, or commonly known as Buya Hamka. This film tells the story of conflict and conflict due to differences in social status. This is supported by the effect of music in creating an atmosphere in each scene which includes dialogue and action of characters that are supported by the setting of time, place and atmosphere in the film. The object of this research focuses on one of the cinematic elements in the film Tenggelamnya Kapal Van Der Wijck, namely music or sound. Music and sound become one of the elements that build the setting of time, place, and atmosphere in the film, which affects the mood of the audience. Music and sound are useful for adding dramatic effects when scenes in the storyline are seen in every shot (shots, scenes, and sequences). The musical characteristics of the film Tenggelamnya Kapal Van Der Wijck which include rhythm, melody, harmony, tempo, song structure and sound color produce a film atmosphere according to the scene in the film which is considered to have an important role in building a dramatic effect on the film that affects the mood of the audience. This research was conducted with a qualitative approach with descriptive analysis method. The data source is direct observation of the film Tenggelamnya Kapal Van Der Wijck. The stage of data collection carried out by researchers is to collect documents which include original film VCD and library studies which include books and scientific writings as comparative material related to material objects and formal objects in this study. Based on these data, an analysis of the musical characteristics of the film Tenggelamnya Kapal Van Der Wijck was conducted was conducted. The results of the study will show that music in the use of musical instruments,
\end{abstract}


major or minor scales, dynamics, motifs, and tempos are characteristics in building a dramatic effect on the film.

Keywords: tenggelamnya Kapal Van Der Wijck.

\section{PENDAHULUAN}

Film sebagai sebuah karya seni yang kolektif memberikan sebuah kenikmatan kepada penonton. Dimana penonton mampu melihat dan merasakan baik secara sadar maupun tidak sadar terhadap suasana yang terbangun. Terbangunnya suasana di dalam sebuah film tidak luput dari unsur suara, gambar dan gerak. Oleh karena itu, pesan yang disampaikan melalui film lebih mudah diterima penonton. Menurut Pratista (2008: 89) menyatakan bahwa film terbentuk dari dua unsur yaitu unsur narasi dan unsur sinematik. Unsur naratif adalah bahan (materi) yang akan diolah, unsur naratif berhubungan dengan aspek cerita atau tema cerita, sedangkan unsur sinematik adalah cara atau gaya untuk mengelola unsur naratif atau bisa dibilang merupakan aspek-aspek teknik pembentukan film. Unsur sinematik terbagi menjadi empat elemen pokok yaitu mise-enscene, sinematografi, editing, dan suara. Aspek suara yang terkandung dalam film TKVDW memiliki makna tersendiri dalam memperlihatkan mood, baik dalam latar waktu, tempat, dan suasana yang terlihat pada beberapa shot, scene dan Sequence.

Suara yang merupakan bagian dari unsur film menjadi tata struktur yang di dalamnya terkandung dialog, musik ataupun efek suara. Dari beberapa unsur suara tersebut saling berkesinambungan dengan fungsi musik yang memberikan kesan imaji kepada penonton, artinya musik dalam film dianggap menjadi elemen penting yang bisa memperkuat latar suasana serta membentuk kesatuan cerita dengan ide tertentu. Menurut Djohan (2009: 87) mengatakan berdasarkan sudut pandang neuropsikologi, proses emosi dimulai dengan adanya rangsangan emosi misalnya berupa rangsangan indra visual, audio, aroma. Artinya emosi yang muncul dapat dipengaruhi dari berbagai hal seperti suara atau musik sebagai sarana ekspresi penonton.

Musik merupakan sebuah ekspresi yang dituangkan dalam media bunyi atau suara. Bunyi atau suara yang dilahirkan memiliki beragam unsur yang saling bersinergi membentuk suatu kesatuan yang utuh. Hal ini menunjukkan bahwa bunyi dapat menjadi media dalam film yang diolah secara musikal baik dalam dimensi latar waktu, ruang dan suasana sesuai dengan karakteristik musik yang dipengaruhi oleh genre (tema) film. Menurut Djohan (2010: 24) mengatakan musik sendiri diakui mempunyai kekuatan untuk mengantar dan menggugah emosi. Baik ditinggalkan melalui penjiwaan terhadap alur cerita, musik dan watak tokoh yang diperankan, maupun sebagai sarana untuk mengekspresikan diri, maka musik tidak dapat dipisahkan dari emosi. Hal ini lah yang menunjukan peran musik sangat besar dalam mempengaruhi mood penonton terhadap suasana dalam menikmati alur cerita pada film.

Film Tenggelamnya Kapal Van Der Wijck merupakan sebuah film drama yang dirilis pada tanggal 19 Desember 2013. Film Tenggelamnya Kapal Van Der Wijck yang disutradarai Sunil Soraya dan diproduksi oleh Ram Soraya ini diadaptasi dari novel mahakarya sastrawan sekaligus budayawan Haji Abdul Malik Karim Amrullah, atau yang biasa dikenal dengan Buya Hamka. Latar belakang film Tenggelamnya Kapal Van Der Wijck mengisahkan tentang pertentangan atau konflik karena adanya perbedaaan status sosial. Konflik yang terjadi pada film Tenggelamnya Kapal Van Der Wijck terlihat pada kisah cinta Zainuddin, seseorang bukan dari garis keturunan Minangkabau dengan Hayati yang merupakan orang garis keturunan Minangkabau. Hal ini menjadi alasan Hayati dijodohkan dengan pemuda keturunan suku Minangkabau bernama Aziz (Pratama, 2017:5). Puncak konflik tersebut terlihat secara dramatis karena didukung oleh musik sebagai pembangun latar suasana yang berpengaruh terhadap mood penonton.

Musik di dalam film TKVDW digunakan untuk menambahkan efek dramatis ketika gambar dan suara sudah tidak mampu lagi memperkuat suasana. Tetapi apabila gambar dan suara yang ada sudah mampu menampilkan efek dramatis, musik juga dapat dipergunakan untuk lebih memperkuat efek ini. Karena dengan menggunakan musik, pembuat film dapat membantu mengendalikan emosi penonton dalam mengikuti cerita. Musik dalam film dapat digunakan untuk menaikkan atau menurunkan emosi penonton, sesuai dengan kebutuhan cerita. Kehadiran musik digunakan untuk merangsang dan mengarahkan perasaan sesuai dengan apa yang dilihat secara visual.

Film TKVDW yang menyangkut kaitan antar konflik dan perbedaan sosial bergerak dari awal hingga akhir cerita. Konflik yang terjadi dalam alur cerita didukung oleh suasana yang terbangun oleh musik. Karakteristik musik pada film TKVDW menghasilkan suasana film 
yang didukung oleh penggunaan instrumen musik serta struktur musik yang dipakai sesuai dengan adegan di dalam film. Adanya penggunaan musik dengan format band dan instrumental di beberapa adegan menjadi ciri khas musik dalam film TKVDW. Selanjutnya penggunaan tangganada mayor atau minor, dinamika, motif, tempo, yang menjadi karakteristik dalam mendukung terciptanya efek dramatis di beberapa scene pada film dalam membangun suasana serta mempengaruhi mood penonton.

Ada beberapa hal yang membuat penulis tertarik dengan film Tenggelamnya Kapal Van Der Wijck tentang karakteristik musik yang menjadi salah satu unsur pembangun suasana yang mempengaruhi suasana dalam alur/plot cerita pada film. Pentingnya penelitian ini terkait karakter musik, yaitu peneliti mencoba mengembangkan ilmu musik pada media film, dimana kurangnya penelitian yang membahas tentang penggunaan idiom-idiom musikal seperti irama; melodi; harmoni; tempo; struktur lagu; serta warna bunyi dalam membangun efek dramatis sebuah film. Dengan demikian, hasil penelitian ini nantinya berupa jabaran tentang karakteristik musik dalam film Tenggelamnya Kapal Van Der Wijck, didukung dengan menggunakan teori musik Barat. Selanjutnya, kajian dalam penelitian ini dapat dilihat dari sudut pandang subjektif.

\section{KAJIAN TEORI}

Musik sebagai bentuk tanggapan emosional dianggap berhubungan dengan psikologis dan psikoterapi. Beberapa indikator musik yang mempengaruhi tubuh manusia. Menurut Djohan (2009: 60) mengatakan bahwa musik dapat menstimulasi terhadap kecenderungan dalam peningkatan energi tubuh, serta menyebabkan tubuh bereaksi, meningkatkan detak jantung, tekanan darah, pernafasan, mendeteksi suhu kulit, aktivitas arus listrik pada permukaan kulit, dan membaca gelombang otak. Sedangkan musik-musik sedatif atau musik relaksasi menurunkan detak jantung dan tekanan darah, menurunkan tingkat rangsang dan secara umum membuat tenang. Artinya secara psikologis dan psikoterasi musik berfungsi sebagai media terapi dalam membangun suasana dan mood pada diri manusia.

Menurut Kristianto (2008: 33) mengatakan bahwa nada dasar suatu musik menjadi salah satu media yang dapat mempengaruhi psikologi atau emosi seseorang. Beberapa data yang telah didapatkan melalui penelitian ilmiah, orang telah meneliti terhadap pengaruh suatu nada dasar terhadap emosional atau psikologi manusia.
Berikut ini beberapa penelitian yang telah dilakukan di antaranya yaitu:

Pertama, Christian Schubart yang merumuskan karakteristik dari nada dasar dalam mempengaruhi psikologi dan emosi manusia diantara lain:

- C Mayor Murni: innocence, sederhana, children's talk.

- C Minor: Deklarasi cinta dan keluh kesah cinta yang sedih.

- Db Mayor: Perasaan yang tidak menentu, tidak dapat tertawa, tapi dapat tersenyum. It's a leering key.

- C\# Minor: Keluh kesah tentang dosa, intimasi dengan Tuhan, keluh kesah dalam pertemanan, dan bohong dalam cinta.

- D Mayor: Megah, sahutan perang, kemenangan.

- D Minor: Melankolis kewanitaan

- Eb Mayor: Kunci tentang cinta, devosi, dan intimasi dengan Tuhan.

- D\# Minor: Kegelisahan dalam sebuah jiwa yang stress, kondisi jiwa terpuruk, tiap ketakutan dan hesitasi dari hati, dan suara hantu.

- E Mayor: Teriakan ribut kegembiraan, tertawa untuk bersuka ria.

- E Minor: Naif, pernyataan cinta dari seorang wanita yang innocent, keluh kesah dengan air mata.

- F Mayor: Tenang dan menurut.

- F Minor: Depresi yang dalam, sahutan kematian, kematian.

- F\# Mayor: Kemenangan atas suatu kesulitan, kebebasan suatu jiwa setelah berjuang.

- F\# Minor: Kunci yang gelap, kemarahan dan tidak senang.

- G Mayor: Kepuasan, tenang, terimakasih terhadap persahabatan 17 sejati, kesetiaan cinta, dan kedamaian.

- G Minor: Ketidaksenangan, merasa tidak nyaman, cemas terhadap suatu kegagalan.

- Ab Mayor: Kunci kematian, keadilan, kebusukan, dan keabadian.

- Ab Minor: Keluh kesah, segala sesuatu tentang perjuangan dengan penuh rintangan.

- A Mayor: Pernyataan cinta yang innocent, keinginan berjumpa lagi pada saat berpisah, kebahagiaan masa muda dan percaya terhadap Tuhan.

- A Minor: Kelembutan suatu karakter, alim secara kewanitaan.

- Bb Mayor: Cinta yang gembira, kesadaran yang baik, harapan untuk lebih baik. 
Bb Minor: Menggambarkan malam hari, ketidakpuasan terhadap Tuhan, dan persiapan untuk bunuh diri.

- B Mayor: Berwarna silau, mengungkapkan keingianan liar, marah, iri, putus asa, dan tiap beban hati berada di kunci ini.

- B Minor: Kesabaran, ketenangan dalam menanti sebuah nasib.

Kedua, Tonempfidungen oleh Helmholtz yang merumuskan karakteristik dari nada dasar dalam mempengaruhi psikologi dan emosi manusia diantara lain:

- C Mayor: Murni, tegas, innocence, perasaan keagamaan yang tinggi.

- Db Mayor: Full of tone, enak didengar, merdu.

- E Mayor: Kegembiraan, keindahan, tercerah, kunci terkuat.

- E Minor: Duka cita, kesedihan.

- F Mayor: Damai, suka cita, cahaya, kekecewaan yang sudah terlampaui.

- F Minor: Melankolis, mengerikan.

- F\# Mayor: Cemerlang, sangat jelas.

- Gb Mayor: Lembut, sangat kaya.

Ketiga, Charpentier yang merumuskan karakteristik dari nada dasar dalam mempengaruhi psikologi dan emosi manusia diantara lain:

- C Mayor: Suka perang.

- C Minor: Tidak jelas dan sedih.

- D Mayor: Kegembiraan dan sangat suka perang.

- D Minor: Serius dan alim.

- Eb Mayor: Kejam dan keras.

- E Mayor: Suka bertengkar dan ramai.

- E Minor: Sedih, bersifat seperti wanita, dan cinta kasih.

- F Mayor: Sangat marah dan temperamen.

- F Minor: Sedih dan tidak jelas.

- G Mayor: Serius dan sangat bagus.

- G Minor: Serius dan sangat bagus

- A Mayor: Gembira dan pastoral.

- A Minor: Lembut dan sedih.

- B Mayor: Kasar dan sedih.

- B Minor: Terpencil dan melankolis.

- Bb Mayor: Sangat bagus dan gembira.

- Bb Minor: Parah dan tidak jelas.

Berdasarkan eksperimen yang dilakukan dari ketiga peneliti di atas dalam merumuskan dan menginterpretasikan nada dasar terkait psikologi dan emosi manusia, maka hal ini membantu peneliti dalam menganalisis efek dramatis terkait suasana di beberapa
Gorga : Jurnal Seni Rupa

Volume 10 Nomor 02 Juli-Desember 2021

p-ISSN: 2301-5942 | e-ISSN: 2580-2380

scene film Tenggelamnya Kapal Van der Wijck. Ketiga interpretasi tersebut dijadikan sebagai rujukan dalam membedah karakteristik musik pada film TKVDW dalam membangun efek dramatis, walaupun setiap orang memiliki perbedaan mengenai interpretasi terhadap nada dasar yang telah dirumuskan.

\section{METODE PENELITIAN}

Pendekatan dalam penelitian ini adalah penelitian kualitatif. Pemilihan pendekatan ini karena peneliti akan melakukan interaksi langsung dalam pengumpulan data terhadap subjek maupun objek dalam penelitian ini. Creswell (2010: 261) mengatakan bahwa dalam penelitian kualitatif peneliti adalah instrumen kunci (researcher as key instrument) yang mengumpulkan sendiri data melalui dokumentasi dan studi pustaka.

Moleong (2006: 3) mengatakan bahwa "penelitian kualitatif merupakan prosedur penelitian yang menghasilkan data kualitatif berupa kata-kata tertulis maupun lisan dari perilaku orang-orang yang diamati”. Berdasarkan hal tersebut, maka metode kualitatif dijadikan sebagai alur pelaksanaan penelitian dalam menganalisis karakteristik musik pada film Tenggelamnya Kapal Van Der Wijck.

\section{HASIL DAN PEMBAHASAN}

\section{Hasil}

Film tenggelamnya Kapal Van Der Wijck yang diadaptasi dari novel karangan Buya Hamka dan diproduksi oleh Soraya Intercine Films, mengisahkan tentang perbedaan latar sosial yang menghalangi hubungan cinta sepasang kekasih sampai berakhir dengan kematian. Dramatik yang terdapat pada cerita memperlihatkan adengan dan aksi dari tokoh-tokoh dalam membangun suasana sedih, ironi, suka cita, kekecewaan, semangat, keluh kesah, kegembiraan, kasih sayang, terpencil, melankolis, marah, putuh asa, bangkit dan lain sebagainya. Suasana tersebut dapat diindentifikasi melalui visual pada film baik pengambaran latar suasana, latar tempat, dan latar waktu, serta konflik yang terbangun antar tokoh, interaksi aksi dan dialog disetiap adengan. Pada setiap adengan tersebut terdapat beberapa penguatan suasana yang dibantu oleh background musik untuk membangun dan membangkitkan efek dramatis dalam mempengaruhi mood penonton.

Background musik pada film TKVDW merupakan musik yang diciptakan oleh grup (band) yang bernama Nidji. Nidji adalah sebuah grup band musik yang beranggotakan enam orang. Grup musik ini berasal dari jakarta yang aktif pada tahun 2002. Konsep musik Nidji 
adalah musik yang beraliran modern rock yang memadukan unsur-unsur seperti progresif, funk, alternatif dan pop. Grup musik ini dipercaya sebagai pengisi jalur suara dalam film TKVDW dinaungi oleh Musica Studio's yang mana mempersiapkan empat buah lagu berjudul Nelangsa, Teroesir, Hidup Tanpa Cintamu, serta Sumpah dan Cinta Matiku. Dari keempat lagu tersebut disajikan juga dan digarap oleh Rundy N Iswara kedalam bentuk instrumental. Namun di beberapa scene film memiliki background musik ilustrasi dalam format instrumental guna mendukung efek dramatis di setiap adengan yang terlihat. Musik tersebut digarap oleh Stevesmith Music Production dalam mengisi musik film TKVDW.

Konsep musik tersebut mengandung konsep pop Britania (British Pop) dengan unsur musik gregorian untuk memberikan kesan megah dan kolosal. Britpop (British Pop) merupakan sebuah aliran musik, yang dipengaruhi oleh aliran seperti alternative rock, indie pop, glam rock, bahkan punk rock, dan juga dianggap sebagai sebuah pergerakan budaya, yang berasal dan populer di Britania Raya. Hal yang mencolok dari Britpop adalah menekankan identitas Britania dan juga mengeluarkan lagu-lagu bersuasana lebih cerah dibandingkan aliran musik Grunge dari Amerika Serikat dan juga para musisi Shoegaze dari Britania Raya itu sendiri (Lestarini, 2014: 23). Artinya, musik pada film TKVDW memakai genre Britania Pop untuk membangun suasana pada setiap adegan di beberapa scene film.

\section{Pembahasan}

Berdasarkan hasil dari pengamatan peneliti terkait karakteristik musikal pada Film Tenggelamnya Kapal Van der Wijck, maka dapat dijabarkan penggunaan karakter musik pada setiap adegan dapat dilihat sebagai berikut.

\section{1). Scene 3. Ext. Sawah (Bendi) - Siang}

Bagian Scene 3 ini merupakan bagian eksposisi pada film TKVDW, dimana Zainuddin diperkenalkan dengan kebiasaan masyarakat Batipuah, Sumatera Barat. Pada adengan ini Zainuddin bertemu dengan Hayati untuk pertama kalinya yang membuat tokoh Zainuddin terpesona akan kecantikan Hayati. Hal ini terlihat pada ekspresi dan diperkuat dengan dialog Zainuddin serta didukung oleh musik sebagai pembangun suasana yang menandakan mulai dari sinilah tumbuh rasa cinta Zainuddin kepada Hayati. Untuk memperkuat suasana dan aksi dari tokoh utama tersebut maka hal ini dipertegas dengan musik lagu yang dibawakan oleh Nidji berjudul Sumpah dan Cinta Matiku, dengan format Band. Berikut deskripsi karakteristik musik yang terdapat pada Scene 3 film TKVDW yaitu:

Tabel 1. Analisis Karakteristik Musik pada Film TKVDW, Scene 3

\begin{tabular}{|c|c|c|}
\hline No. & $\begin{array}{c}\text { Analisis } \\
\text { Karakteristik } \\
\text { Musik } \\
\text { Scene } 3\end{array}$ & Keterangan \\
\hline 1. & Instrumen Musik & $\begin{array}{l}\text { Piano, Guitar Electric, Bass } \\
\text { Electric, String Ensamble (Violin, } \\
\text { Viola, Violoncello, dan } \\
\text { Contrabass), } \\
\text { (Grandcassa, Floor), dan Drum } \\
\text { Set }\end{array}$ \\
\hline 2. & Irama & $\begin{array}{l}\text { Sukat } 4 / 4 \text {, artinya terdapat empat } \\
\text { buah not } 1 / 4 \text { dalam setiap satu } \\
\text { birama. }\end{array}$ \\
\hline 3. & Melodi & $\begin{array}{l}\text { Sederhana, dimainkan oleh } \\
\text { instrumen String Ensamble }\end{array}$ \\
\hline 4. & Harmoni & G Minor Asli \\
\hline 5. & Tempo & $65 \mathrm{bpm}$ \\
\hline 6. & Struktur Lagu & $\begin{array}{l}\text { Two Part Song Form (Lagu Dua } \\
\text { Bagian) }\end{array}$ \\
\hline 7. & Warna Bunyi & Band Orkestra \\
\hline
\end{tabular}

Berdasarkan analisis karakteristik di atas, maka background musik Scene 3 pada awal film memiliki nada dasar G Minor Asli. Menurut Charpentier nada dasar G Minor Asli mengambarkan suasana serius dan sangat bagus. Artinya musik ini mendukung suasana keseriusan Zainuddin dalam ketertarikan terhadap Hayati saat pertama kali bertemu. Hal ini didukung dengan pengambilan close up dimana digambarkan ekspresi wajah Zainuddin.

\section{2). Scene 9. Kedai - Malam}

Bagian Scene 9 ini merupakan bagian cerita film dimana Zainuddin berkenalan dengan Hayati untuk pertama kali. Latar tempat pertemuan ini di sebuah warung pada malam hari dengan suasana hujan. Pertemuan ini awal ketertarikan Hayati kepada Zainuddin karena kebaikanya yang tulus. Musik yang dipakai dalam bagian ini merupakan lagu yang dibawakan oleh Nidji berjudul Sumpah dan Cinta Matiku, dengan format instrumental. Berikut analisis karakteristik musik yang terdapat pada Scene 9 film TKVDW yaitu:

Tabel 2. Analisis Karakteristik Musik pada Film TKVDW, Scene 9

\begin{tabular}{|l|l|l|}
\hline No. & $\begin{array}{c}\text { Analisis Karakteristik } \\
\text { Musik } \\
\text { Scene 9 }\end{array}$ & \multicolumn{1}{|c|}{ Keterangan } \\
\hline $\mathbf{1 .}$ & Instrumen Musik & Piano, String Ensamble \\
& & (Violin, Viola, \\
& & Violoncello, dan \\
& & Contrabass), Percussion \\
& & (Grandcassa, Floor), \\
& & dan Vokal \\
\hline
\end{tabular}




\begin{tabular}{|l|l|l|}
\hline & \\
\hline $\mathbf{2 .}$ & Irama & $\begin{array}{l}\text { Sukat 4/4, artinya } \\
\text { terdapat empat buah not } \\
1 / 4 \text { dalam setiap satu } \\
\text { birama. }\end{array}$ \\
\hline $\mathbf{3 .}$ & Melodi & $\begin{array}{l}\text { Sederhana, dimainkan } \\
\text { oleh Vokal }\end{array}$ \\
\hline $\mathbf{4 .}$ & Harmoni & Fis Minor Asli \\
\hline $\mathbf{5 .}$ & Tempo & $\begin{array}{l}\text { Tw bpm } \\
\text { (Lagu Dua Bagian) }\end{array}$ \\
\hline $\mathbf{6 .}$ & Struktur Lagu & Orkestra \\
\hline $\mathbf{7 .}$ & Warna Bunyi & \\
\hline
\end{tabular}

Bagian Scene selanjutnya yaitu Scene 10-13, ini merupakan bagian cerita film dimana Zainuddin dengan Hayati saling bertukar surat. Musik yang dipakai dalam bagian ini sama seperti bagian Scene 10 yaitu merupakan lagu yang dibawakan oleh Nidji berjudul Sumpah dan Cinta Matiku, dengan format instrumental. Terkait dengan analisis karakteristik musik yang dipakai adalah sama dengan bagian Scene 9.

Berdasarkan analisis karakteristik di atas, maka background musik Scene 9, 10 dan 13 pada awal film memiliki nada dasar Fis Minor Asli. Musik menggambarkan suasana adegan kesenangan Hayati dan Zainuddin yang direpresentasikan pada melodi lagu dalam instrumen string. Situasi yang digambarkan juga dipertegas dengan dialog dan ekspresi dari tokoh untuk dalam membangun suasana psikologi dari tokohtokoh tersebut.

\section{3). Scene 17. Ext. Rumah Mandeh Jamilah - Senja}

Bagian Scene 17 ini merupakan bagian cerita film dimana Zainuddin meninggalkan Batipuh. Di bagian ini diperlihatkan adegan dimana Zainuddin berangkat ke Padang Panjang dan berpisah dengan Mandeh. Musik yang dipakai dalam bagian ini merupakan lagu instrumental yang dimainkan oleh Piano, Vokal, Seruling dengan iringan String Ensamble. Berikut analisis karakteristik musik yang terdapat pada Scene 18 film TKVDW yaitu:

Tabel 3. Analisis Karakteristik Musik pada Film TKVDW, Scene 17

\begin{tabular}{|c|c|c|}
\hline No. & $\begin{array}{c}\text { Analisis Karakteristik } \\
\text { Musik } \\
\text { Scene } 17\end{array}$ & Keterangan \\
\hline 1. & Instrumen Musik & $\begin{array}{l}\text { Piano, String Ensamble } \\
\text { (Violin, Viola, } \\
\text { Violoncello, dan } \\
\text { Contrabass), Seruling, } \\
\text { dan Vokal }\end{array}$ \\
\hline 2. & Irama & $\begin{array}{l}\text { Sukat } 6 / 8 \text {, artinya } \\
\text { terdapat enam buah not } \\
1 / 8 \text { dalam setiap satu } \\
\text { birama. }\end{array}$ \\
\hline
\end{tabular}

Gorga : Jurnal Seni Rupa

Volume 10 Nomor 02 Juli-Desember 2021 p-ISSN: 2301-5942 | e-ISSN: 2580-2380

\begin{tabular}{|l|l|l|}
\hline 3. & Melodi & $\begin{array}{l}\text { Bebas (melodi solo } \\
\text { bebas), dimainkan oleh } \\
\text { Vokal, dan Seruling }\end{array}$ \\
\hline $\mathbf{4 .}$ & Harmoni & G Minor Asli \\
\hline $\mathbf{5 .}$ & Tempo & 100 bpm \\
\hline $\mathbf{6 .}$ & Struktur Lagu & $\begin{array}{l}\text { Two Part Song Form } \\
\text { (Lagu Dua Bagian) }\end{array}$ \\
\hline $\mathbf{7 .}$ & Warna Bunyi & Orkestra \\
\hline
\end{tabular}

Berdasarkan analisis karakteristik di atas, maka background musik Scene 17 pada awal film memiliki nada dasar G Minor Asli. Menurut Schubart nada dasar Fis Minor Asli mengambarkan suasana ketidaksenangan, merasa tidak nyaman, cemas terhadap suatu kegagalan. Artinya suasana tersebut sangat didukung oleh visualisasi dimana kepergian Zainuddin meninggalkan Batipuh dengan berat hati dilepas oleh Mandeh Jamilah. Hal ini terlihat pada aksi Mandeh Jamilah melihat kepergian Zainuddin dari jendela rumahnya.

\section{4). Scene 18. Ext. Danau - Sore}

Bagian Scene 18 ini merupakan bagian cerita film dimana Zainuddin meninggalkan Batipuah. Di bagian ini diperlihatkan adegan dimana Zainuddin berpisah dengan Hayati, mereka berdua saling berjanji untuk mempertahankan cinta. Musik yang dipakai dalam bagian ini merupakan lagu instrumental yang dimainkan oleh Piano, Vokal, Seruling dengan iringan String Ensamble. Berikut analisis karakteristik musik yang terdapat pada Scene 18 film TKVDW adalah:

Tabel 4. Analisis Karakteristik Musik pada Film TKVDW, Scene 18

\begin{tabular}{|l|l|l|}
\hline No & \multicolumn{1}{|c|}{$\begin{array}{c}\text { Analisis Karakteristik } \\
\text { Musik } \\
\text { Scene 18 }\end{array}$} & \multicolumn{1}{c|}{ Keterangan } \\
\hline 1. & Instrumen Musik & $\begin{array}{l}\text { Piano, Guitar Electric, } \\
\text { Bass Electric, String } \\
\text { Ensamble (Violin, Viola, } \\
\text { Violoncello, dan } \\
\text { Contrabass), dan Vokal }\end{array}$ \\
\hline $\mathbf{2 .}$ & Irama & $\begin{array}{l}\text { Sukat 4/4, artinya } \\
\text { terdapat empat buah not } \\
1 / 4 \text { dalam setiap satu } \\
\text { birama. }\end{array}$ \\
\hline 3. & Melodi & $\begin{array}{l}\text { Sederhana, dimainkan } \\
\text { oleh Vokal }\end{array}$ \\
\hline 4. & Harmoni & G Minor Asli \\
\hline 5. & Tempo & 65 bpm \\
\hline 6. & Struktur Lagu & $\begin{array}{l}\text { Two Part Song Form } \\
\text { (Lagu Dua Bagian) }\end{array}$ \\
\hline $\mathbf{7 .}$ & Warna Bunyi & Band, Orkestra \\
\hline & &
\end{tabular}

Berdasarkan analisis karakteristik di atas, maka background musik Scene 18 pada awal film memiliki nada dasar G Minor Asli. Menurut Schubart nada dasar Fis Minor Asli mengambarkan suasana ketidaksenangan, merasa tidak nyaman, cemas 
Gorga : Jurnal Seni Rupa

Volume 10 Nomor 02 Juli-Desember 2021

p-ISSN: 2301-5942 | e-ISSN: 2580-2380

terhadap suatu kegagalan. Artinya musik sangat berperan dalam adegan ini, dimana Hayati dan Zainuddin saling mengekspresikan kesedihannya yang mereka alami karena penolakan Zainuddin di Batipuh.

\section{5). Scene 27. Int. Rumah Aziz - Siang}

Bagian Scene 27 ini merupakan bagian cerita film dimana Aziz terpesona melihat Hayati yang berpakaian seperti orang-orang di kota. Musik yang dipakai dalam bagian ini merupakan musik instrumental dengan instrumen Solo Violoncello diiringi Piano. Berikut analisis karakteristik musik yang terdapat pada Scene 27 film TKVDW adalah sebagai berikut:

Tabel 5. Analisis Karakteristik Musik pada Film TKVDW, Scene 27

\begin{tabular}{|l|l|l|}
\hline No & \multicolumn{1}{|c|}{$\begin{array}{c}\text { Analisis Karakteristik } \\
\text { Musik } \\
\text { Scene 27 }\end{array}$} & \multicolumn{1}{|c|}{ Keterangan } \\
\hline 1. & Instrumen Musik & Piano, Violoncello \\
\hline $\mathbf{2 .}$ & Irama & $\begin{array}{l}\text { Sukat 4/4, artinya } \\
\text { terdapat empat buah not } \\
1 / 4 \text { dalam setiap satu } \\
\text { birama. }\end{array}$ \\
\hline $\mathbf{3 .}$ & Melodi & $\begin{array}{l}\text { Sederhana, dimainkan } \\
\text { oleh Violoncello }\end{array}$ \\
\hline 4. & Harmoni & D Minor Asli \\
\hline $\mathbf{5 .}$ & Tempo & 100 bpm \\
\hline 6. & Struktur Lagu & $\begin{array}{l}\text { One Part Song Form } \\
\text { (Lagu Satu Bagian) }\end{array}$ \\
\hline 7. & Warna Bunyi & Lembut, Instrumental \\
\hline
\end{tabular}

Berdasarkan analisis karakteristik di atas, maka background musik Scene 27 pada awal film memiliki nada dasar D Minor Asli. Menurut Schubart nada dasar D Minor Asli mengambarkan suasana Melankolis kewanitaan. Artinya musik mendukung suasana ketika Aziz melihat Hayati dengan pakaian dan gaya ke'barat'-an sesuai dengan gaya hidup Aziz. Di adegan inilah terlihat ekspresi kekaguman Aziz terhadap sosok Hayati, didukung dengan pengambilan gambar medium shoot.

\section{6). Scene 29. Ext. Lapangan Pacuan Kuda - Siang}

Bagian Scene 29 ini merupakan bagian cerita film dimana Zainuddin bertemu dengan Hayati di acara pacuan kuda yang diadakan di Kota Padang Panjang. Musik yang dipakai dalam bagian ini sama dengan bagian Scene 9 dan Scene 10 yaitu merupakan lagu yang dibawakan oleh Nidji berjudul Sumpah dan Cinta Matiku, dengan format instrumental. Terkait dengan analisis karakteristik musik yang dipakai adalah sama dengan bagian Scene 9 dan Scene 10.

Bagian selanjutnya masih dalam satu scene. Bagian ini merupakan bagian cerita film dimana Hayati dipaksa oleh teman Aziz untuk pergi meninggalkan Zainuddin. Musik yang dipakai dalam bagian ini merupakan musik instrumental dengan instrumen Solo Vokal diiringi Ensamble String. Berikut analisis karakteristik musik yang terdapat pada Scene 29 film TKVDW adalah sebagai berikut:

Tabel 6. Analisis Karakteristik Musik pada Film TKVDW, Scene 29

\begin{tabular}{|l|l|l|}
\hline No & \multicolumn{1}{|c|}{$\begin{array}{c}\text { Analisis Karakteristik } \\
\text { Musik } \\
\text { Scene 29 }\end{array}$} & \multicolumn{1}{|c|}{ Keterangan } \\
\hline 1. & Instrumen Musik & $\begin{array}{l}\text { Vokal, String Ensamble } \\
\text { (Violin, Viola, } \\
\text { Violoncello, dan } \\
\text { Contrabass) }\end{array}$ \\
\hline 2. & Irama & $\begin{array}{l}\text { Sukat 4/4, artinya } \\
\text { terdapat empat buah not } \\
1 / 4 \text { dalam setiap satu } \\
\text { birama. }\end{array}$ \\
\hline 3. & Melodi & $\begin{array}{l}\text { Sederhana, dimainkan } \\
\text { oleh Vokal }\end{array}$ \\
\hline 4. & Harmoni & E Minor Asli \\
\hline $\mathbf{5 .}$ & Tempo & 60 bpm \\
\hline 6. & Struktur Lagu & $\begin{array}{l}\text { One Part Song Form } \\
\text { (Lagu Satu Bagian) }\end{array}$ \\
\hline $\mathbf{7 .}$ & Warna Bunyi & Lembut, Instrumental \\
\hline
\end{tabular}

Berdasarkan analisis karakteristik di atas, maka background musik Scene 29 pada awal film memiliki nada dasar E Minor Asli. Menurut Schubart nada dasar E Minor Asli mengambarkan suasana naif, pernyataan cinta dari seorang wanita yang innocent, keluh kesah dengan air mata. Artinya musik membantu mendukung pergerakan aktor, dimana terlihat Hayati akhirnya bisa bertemu dengan Zainuddin di Gelanggang Pacuan Kuda.

\section{7). Scene 35. Int. Rumah Datuak - Malam}

Bagian Scene 35 ini merupakan bagian cerita film dimana Hayati dipinang oleh Aziz dan Zainuddin, Hayati dihadapkan dengan para niniak mamak dan dengan terpaksa menerima pinangan Aziz. Selanjutnya, Niniak Mamak mengirim surat penolakan lamaran Zainuddin. Musik yang dipakai dalam bagian ini merupakan musik instrumental format orkestra dengan instrumen Ensamble String dan Koor. Berikut analisis karakteristik musik yang terdapat pada Scene 35 film TKVDW adalah sebagai berikut:

Tabel 7. Analisis Karakteristik Musik pada Film TKVDW, Scene 35

\begin{tabular}{|l|c|l|}
\hline No & $\begin{array}{c}\text { Analisis Karakteristik } \\
\text { Musik }\end{array}$ & \\
\hline 1. & Scene 35 & Keterangan \\
\hline
\end{tabular}




\begin{tabular}{|c|c|c|}
\hline & & $\begin{array}{l}\text { Violoncello, dan } \\
\text { Contrabass) }\end{array}$ \\
\hline 2. & Irama & $\begin{array}{l}\text { Sukat } 4 / 4 \text {, artinya } \\
\text { terdapat empat buah not } \\
1 / 4 \text { dalam setiap satu } \\
\text { birama. }\end{array}$ \\
\hline 3. & Melodi & $\begin{array}{l}\text { Sederhana, dimainkan } \\
\text { oleh Vokal }\end{array}$ \\
\hline 4. & Harmoni & D Minor Asli \\
\hline 5. & Tempo & $60 \mathrm{bpm}$ \\
\hline 6. & Struktur Lagu & $\begin{array}{l}\text { Two Part Song Form } \\
\text { (Lagu Dua Bagian) }\end{array}$ \\
\hline 7. & Warna Bunyi & Lembut, Instrumental \\
\hline
\end{tabular}

Berdasarkan analisis karakteristik di atas, maka background musik Scene 35 pada awal film memiliki nada dasar D Minor Asli. Menurut Schubart nada dasar D Minor Asli mengambarkan suasana melankolis kewanitaan. Artinya musik mendukung suasana hati Hayati yang hancur, ketika dipaksa untuk menerima lamaran Aziz dan menolak lamaran Zainuddin. Terlihat dari ekspresi Hayati dengan pengambilan gambar secara close up.

\section{8). Scene 48. Int. Kamar Tidur - Siang}

Bagian Scene 48 ini merupakan bagian cerita film dimana Hayati dan Aziz menemui Zainuddin yang sakit dan stres. Musik pada bagian ini merupakan musik instrumental yang dimainkan oleh Koor. Berikut analisis karakteristik musik yang terdapat pada Scene 48 film TKVDW adalah sebagai berikut:

Tabel 8. Analisis Karakteristik Musik pada Film TKVDW, Scene 48

\begin{tabular}{|l|l|l|}
\hline No. & \multicolumn{1}{|c|}{$\begin{array}{c}\text { Analisis Karakteristik } \\
\text { Musik } \\
\text { Scene 48 }\end{array}$} & \multicolumn{1}{c|}{ Keterangan } \\
\hline 1. & Instrumen Musik & Koor (Paduan Suara) \\
\hline 2. & Irama & $\begin{array}{l}\text { Sukat 4/4, artinya } \\
\text { terdapat empat buah not } \\
1 / 4 \text { dalam setiap satu } \\
\text { birama. }\end{array}$ \\
\hline 3. & Melodi & $\begin{array}{l}\text { Sederhana, dimainkan } \\
\text { oleh Vokal }\end{array}$ \\
\hline 4. & Harmoni & G Minor Asli \\
\hline 5. & Tempo & 60 bpm \\
\hline 6. & Struktur Lagu & $\begin{array}{l}\text { One Part Song Form } \\
\text { (Lagu Satu Bagian) }\end{array}$ \\
\hline 7. & Warna Bunyi & Instrumental \\
\hline
\end{tabular}

Berdasarkan analisis karakteristik di atas, maka background musik Scene 48 pada awal film memiliki nada dasar G Minor Asli. Menurut Schubart nada dasar G Minor Asli mengambarkan suasana ketidaksenangan, merasa tidak nyaman, cemas terhadap suatu kegagalan. Artinya musik sangat berperan dalam adegan ini, dimana musik mendukung dalam adegan Hayati yang merasa bersalah terhadap keputusan yang telah diambilnya.
Gorga : Jurnal Seni Rupa

Volume 10 Nomor 02 Juli-Desember 2021 p-ISSN: 2301-5942 | e-ISSN: 2580-2380

\section{9). Scene 56. Int. Ruang Kerja - Siang}

Pada Scene 56 ini merupakan bagian cerita film dimana diperlihatkan kehidupan Hayati dengan Aziz dan Zainuddin dengan Muluk. Pada adegan ini diperlihatkan awal mula keberhasilan Zainuddin, dimana karya novelnya mulai disukai oleh masyarakat. Musik pada bagian ini merupakan lagu Band Nidji yang berjudul Teroesir. Berikut analisis karakteristik musik yang terdapat pada Scene 56 film TKVDW adalah sebagai berikut:

Tabel 9. Analisis Karakteristik Musik pada Film TKVDW, Scene 56

\begin{tabular}{|l|l|l|}
\hline No. & \multicolumn{1}{|c|}{$\begin{array}{c}\text { Analisis Karakteristik } \\
\text { Musik } \\
\text { Scene 56 }\end{array}$} & \multicolumn{1}{|c|}{ Keterangan } \\
\hline 1. & Instrumen Musik & $\begin{array}{l}\text { Piano, String Ensamble } \\
\text { (Violin, Viola, } \\
\text { Violoncello, dan } \\
\text { Contrabass), Percussion } \\
\text { (Grandcassa, Floor) } \\
\text { dan Vokal }\end{array}$ \\
\hline $\mathbf{2 .}$ & Irama & $\begin{array}{l}\text { Sukat 4/4, artinya } \\
\text { terdapat empat buah not } \\
1 / 4 \text { dalam setiap satu } \\
\text { birama. }\end{array}$ \\
\hline 3. & Melodi & $\begin{array}{l}\text { Sederhana, dimainkan } \\
\text { oleh Vokal }\end{array}$ \\
\hline 4. & Harmoni & D Minor Asli \\
\hline $\mathbf{5 .}$ & Tempo & 100 bpm \\
\hline $\mathbf{6 .}$ & Struktur Lagu & $\begin{array}{l}\text { Two Part Song Form } \\
\text { (Lagu Satu Bagian) }\end{array}$ \\
\hline $\mathbf{7 .}$ & Warna Bunyi & Band, Orkestra \\
\hline
\end{tabular}

Berdasarkan analisis karakteristik di atas, maka background musik Scene 56 pada awal film memiliki nada dasar D Minor Asli. Menurut Charpentier nada dasar D Minor Asli mengambarkan suasana Serius dan alim. Artinya musik suasana ini mendukung keadaan kebangkitan dari tokoh utama Zainuddin dan kebahagiaan Hayati, dimana shoot gambar ditampilkan secara bergantian, serta didukung dengan ekspresi yang diperlihatkan oleh tokoh tersebut.

\section{0). Scene 102. Int. Kamar Tidur - Siang}

Bagian Scene 102 ini merupakan bagian cerita tentang Aziz yang menitipkan Hayati kepada Zainuddin. Selanjutnya, Aziz pergi untuk mencari pekerjaan, dan berjanji akan kembali ketika keadaan keuangan Aziz sudah membaik. Musik pada bagian ini merupakan musik instrumental yang dimainkan oleh Violoncello Solo dengan iringan Piano dan Ensamble String. Berikut analisis karakteristik musik yang terdapat pada Scene 102 film TKVDW adalah sebagai berikut:

Tabel 10. Analisis Karakteristik Musik pada Film TKVDW, Scene 102

\begin{tabular}{|l|c|c|}
\hline No. & $\begin{array}{c}\text { Analisis Karakteristik } \\
\text { Musik } \\
\end{array}$ & Keterangan \\
& Scene 102 & \\
\hline
\end{tabular}




\begin{tabular}{|l|l|l|}
\hline & \\
\hline $\mathbf{1 .}$ & Instrumen Musik & $\begin{array}{l}\text { Violoncello Solo, } \\
\text { Ensamble String, Piano }\end{array}$ \\
\hline $\mathbf{2 .}$ & Irama & $\begin{array}{l}\text { Sukat 4/4, artinya } \\
\text { terdapat empat buah not } \\
1 / 4 \text { dalam setiap satu } \\
\text { birama. }\end{array}$ \\
\hline $\mathbf{3 .}$ & Melodi & Bebas, solo \\
\hline $\mathbf{4 .}$ & Harmoni & G Minor Asli \\
\hline $\mathbf{5 .}$ & Tempo & 60 bpm \\
\hline $\mathbf{6 .}$ & Struktur Lagu & $\begin{array}{l}\text { One Part Song Form } \\
\text { (Lagu Satu Bagian) }\end{array}$ \\
\hline $\mathbf{7 .}$ & Warna Bunyi & Instrumental, Lembut \\
\hline
\end{tabular}

Berdasarkan analisis karakteristik di atas, maka background musik Scene 102 pada awal film memiliki nada dasar G Minor Asli. Menurut Schubart nada dasar G Minor Asli mengambarkan suasana ketidaksenangan, merasa tidak nyaman, cemas terhadap suatu kegagalan. Artinya musik menggambarkan dialog dan ekspresi wajah yang cemas dan takut terhadap keadaannya pada adegan tersebut. Didukung dengan pengambilan gambar close up.

\section{1). Scene 105. Ext. Teras Rumah - Malam}

Pada bagian Scene 105 ini merupakan bagian cerita tentang Hayati yang merasa ada yang salah dengan dirinya, sehingga Zainuddin bersikap dingin kepadanya. Hayati bertanya kepada Muluk tentang apa yang dia rasakan. Kemudian Hayati dibawa oleh Muluk ke dalam ruangan kerja Zainuddin, di sana ia diperlihatkan foto dirinya yang dipajang oleh Zainuddin. Musik pada bagian ini merupakan musik instrumental yang dimainkan oleh Vokal dan iringan Piano. Berikut analisis karakteristik musik yang terdapat pada Scene 105 film TKVDW adalah sebagai berikut:

Tabel 11. Analisis Karakteristik Musik pada Film TKVDW, Scene 105

\begin{tabular}{|l|l|l|}
\hline No. & \multicolumn{1}{|c|}{$\begin{array}{c}\text { Analisis Karakteristik } \\
\text { Musik } \\
\text { Scene 105 }\end{array}$} & \multicolumn{1}{|c|}{ Keterangan } \\
\hline 1. & Instrumen Musik & Piano \\
\hline 2. & Irama & $\begin{array}{l}\text { Sukat 4/4, artinya } \\
\text { terdapat empat buah not } \\
1 / 4 \text { dalam setiap satu } \\
\text { birama. }\end{array}$ \\
\hline 3. & Melodi & Bebas, solo \\
\hline 4. & Harmoni & E Minor Asli \\
\hline 5. & Tempo & 100 bpm \\
\hline 6. & Struktur Lagu & $\begin{array}{l}\text { One Part Song Form } \\
\text { (Lagu Satu Bagian) }\end{array}$ \\
\hline 7. & Warna Bunyi & Instrumental, Lembut \\
\hline
\end{tabular}

Berdasarkan analisis karakteristik di atas, maka background musik Scene 105 pada awal film memiliki nada dasar E Minor Asli. Menurut Schubart nada dasar E Minor Asli mengambarkan suasana naif, pernyataan
Gorga : Jurnal Seni Rupa

Volume 10 Nomor 02 Juli-Desember 2021 p-ISSN: 2301-5942 | e-ISSN: 2580-2380

cinta dari seorang wanita yang innocent, keluh kesah dengan air mata. Artinya musik menaikkan efek dramatis kesedihan hayati ketika melihat lukisan dirinya di ruang kerja Zainuddin yag selama ini tidak Hayati ketahui.

\section{2). Scene 120. Int. Rumah Zainuddin - Malam}

Pada bagian Scene 120 ini merupakan bagian cerita tentang Zainuddin yang sedang membaca surat terakhir dari Hayati. Pada adegan ini, timbul penyesalan yang mendalam yaang dirasakan oleh Zainuddin. Pada adegan ini juga diperlihatkan Kapal Van der Wijck yang tenggelam bersama Hayati yang memegang foto Zainuddin. Musik pada bagian ini merupakan musik instrumental yang dimainkan oleh Piano. Berikut analisis karakteristik musik yang terdapat pada Scene 120 film TKVDW adalah sebagai berikut:

Tabel 12. Analisis Karakteristik Musik pada Film TKVDW, Scene 120

\begin{tabular}{|l|l|l|}
\hline No. & \multicolumn{1}{|c|}{$\begin{array}{c}\text { Analisis Karakteristik } \\
\text { Musik } \\
\text { Scene 120 }\end{array}$} & \multicolumn{1}{c|}{ Keterangan } \\
\hline 1. & Instrumen Musik & Piano \\
\hline 2. & Irama & $\begin{array}{l}\text { Sukat 7/8, artinya } \\
\text { terdapat tujuh buah not } \\
1 / 8 \text { dalam setiap satu } \\
\text { birama. }\end{array}$ \\
\hline 3. & Melodi & Solo Koor \\
\hline 4. & Harmoni & F Minor Asli \\
\hline 5. & Tempo & 90 bpm \\
\hline 6. & Struktur Lagu & $\begin{array}{l}\text { One Part Song Form } \\
\text { (Lagu Dua Bagian) }\end{array}$ \\
\hline 7. & Warna Bunyi & Instrumental, Lembut \\
\hline
\end{tabular}

Berdasarkan analisis karakteristik di atas, maka background musik Scene 120 pada awal film memiliki nada dasar F Minor Asli. Menurut Schubart nada dasar F Minor Asli mengambarkan suasana depresi yang dalam, sahutan kematian, kematian. Artinya musik menggambarkan penyesalan tokoh Zainuddin terhadap keputusannya kepada Hayati.

\section{3). Scene 127. Int. Ruang Rumah Sakit - Siang}

Pada bagian Scene 127 ini diperlihatkan bahwa Hayati berhasil diselamatkan. Zainuddin menyampaikan penyesalannya. Pada adegan ini, kemudian Hayati meninggal dunia, disusul oleh tangisan dan penyesalan Zainuddin. Musik pada bagian ini merupakan musik instrumental yang dimainkan oleh Vokal dan Ensamble String. Berikut analisis karakteristik musik yang terdapat pada Scene 127 film TKVDW adalah sebagai berikut: 


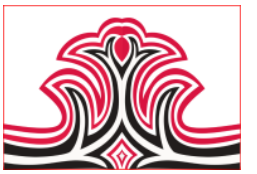

Tabel 13. Analisis Karakteristik Musik pada Film TKVDW, Scene 127

\begin{tabular}{|l|l|l|}
\hline No. & \multicolumn{1}{|c|}{$\begin{array}{c}\text { Analisis Karakteristik } \\
\text { Musik } \\
\text { Scene 127 }\end{array}$} & \multicolumn{1}{|c|}{ Keterangan } \\
\hline 1. & Instrumen Musik & Piano, Ensamble String \\
\hline $\mathbf{2 .}$ & Irama & $\begin{array}{l}\text { Sukat 4/4, artinya } \\
\text { terdapat empat buah not } \\
1 / 4 \text { dalam setiap satu } \\
\text { birama. }\end{array}$ \\
\hline $\mathbf{3 .}$ & Melodi & Solo Koor, dan String \\
\hline 4. & Harmoni & Fes/E Minor Asli \\
\hline $\mathbf{5 .}$ & Tempo & 70 bpm \\
\hline 6. & Struktur Lagu & $\begin{array}{l}\text { Two Part Song Form } \\
\text { (Lagu Dua Bagian) }\end{array}$ \\
\hline 7. & Warna Bunyi & Instrumental, Lembut \\
\hline & & \\
\hline
\end{tabular}

Berdasarkan analisis karakteristik di atas, maka background musik Scene 127 pada awal film memiliki nada dasar Fes/E Minor Asli. Menurut Tonempfidungen oleh Helmholtz nada dasar Fes/E Minor Asli mengambarkan suasana duka cita, kesedihan. Artinya musik merepresantasikan suasana pada gambar yang memperlihatkan Zainuddin terpuruk dalam kesedihan karena kematian Hayati.

\section{KESIMPULAN DAN SARAN}

\section{Kesimpulan}

Berdasarkan penelitian terhadap karakteristik dan fungsi musik pada film Tenggelamnya Kapal Van der Wijck, maka dapat disimpulkan bahwa pemakaian instrumen musik (instrumentasi), penggunaan tangganada mayor atau minor, dinamika musikal, motif, dan tempo menjadi karakteristik musik dalam mempengaruhi mood penonton. Selain karakteristik musik, fungsi musik di dalam film Tenggelamnya Kapal Van Der Wijck juga mempengaruhi latar suasana film, dimana fungsi tersebut antara lain memperkuat pesan yang disampaikan kepada penonton, menciptakan kesinambungan antar adegan, memperkuat karakter dan perwatakan tokoh, serta menambah nilai estetik dalam film.

\section{Saran}

Dalam penelitian ini baik dalam perspektif objek formal maupun objek material diharapkan agar menjadi acuan dan referensi bagi penelitian selanjutnya, terkait dengan karakteristik dan fungsi musik pada film Tenggelamnya Kapal Van der Wijck. Selanjutnya, penelitian ini tentunya masih banyak memiliki kekurangan dan masih belum sempurna, sehingga diharapkan bagi peneliti berikutnya untuk meneliti lebih mendalam dari berbagai disiplin ilmu (multidisiplin) terkait objek material maupun objek formal. Kemudian, hasil penelitian ini lebih subjektif dalam memaknai musik dalam pembangun efek dramatis dalam setiap adengan pada film karena
Gorga : Jurnal Seni Rupa

Volume 10 Nomor 02 Juli-Desember 2021 p-ISSN: 2301-5942 | e-ISSN: 2580-2380

disetiap orang memiliki interpretasi masing-masing dalam memberikan kesan terhadap nada dasar yang telah dirumuskan.

\section{DAFTAR RUJUKAN}

Cresswell, John W. (2010). Research Design Pendekatan Kualitatif, Kuantitatif, dan Mixed. Yogyakarta: Pustaka Belajar.

Djohan. (2009). Psikologi Musik. Yogyakarta: Penerbit Best Publisher.

Kristianto, Y.P, Sumono. (2008). Pengantar Ilmu Akustik Suara dan Pendengaran. Jakarta: Remaja Kosdakaya.

Lestarini, Aulia, Anggia. (2014). Perkembangan Internasional British Pop Culture Pasca Perang Dunia Kedua. Skripsi. Surabaya: Universitas Airlangga.

Moleong, J, Lexy. (2006). Metodologi Penelitian Kualitatif. Bandung: PT. Remaja Rosdakarya.

Pratama, Haria Nanda. (2017). Materalistis dan Alur Dramatik pada Film Tenggelamnya Kapal Van Der Wijck. Tesis. Padangpanjang: Pascasarjana Institut Seni Indonesia Padang Panjang.

Pratista, Himawan. (2008). Memahami Film. Yogyakarta: Homerian Pustaka. 